\title{
Penegakan Hukum Terhadap Pelanggaran atas Ketentuan Perizinan Toko Swalayan di Wilayah Provinsi Bali
}

\author{
I Nengah Suantra ${ }^{1}$, Made Nurmawati ${ }^{2}$
}

${ }^{1}$ Fakultas Hukum Universitas Udayana, E-mail: nengah_suantra@unud.ac.id 2Fakultas Hukum Universitas Udayana, E-mail: made_nurmawati@unud.ac.id

\begin{tabular}{l}
\hline Info Artikel \\
\hline Masuk: 3 Juni 2019 \\
Diterima: 26 Juli 2019 \\
Terbit: 31 Juli 2019 \\
Keywords : \\
License; law infringement; law \\
enforcement; sanction; \\
supermarket \\
Korresponding Author: \\
I Nengah Suantra, E-mail: \\
nengah_suantra@unud.ac.id \\
penegakan hukum; sanks; toko \\
swalayan
\end{tabular}

\begin{abstract}
The Self-service shop developing into the countryside, however there are those who do not have licenses and violated licensing regulation. Therefore, violations of law were identified and analyzed by supermarkets, and law enforcement by SATPOL PP against these violations. Research uses normative legal research methods; the approach is the legislative approach, concepts, and philosophy. Data sources consist of primary, secondary, and tertiary legal materials and the results of interviews with informants. The arrangement of the Self-service shop's licenses is performed with Local Regulation, Regent Regulation, Regulation of Mayor, and/or the Mayor's Decision, the Mayor's Instructions and Regent's Circular Letter. Klungkung District does not have a regulation for supermarket yet. The legality of the Self-service shop is in the form of IUTS/IUTM, IUPP, DUTS, and DUPP. Tabanan and Klungkung District use SIUP and TDP. The law infringement of the Self-service shop is: violation of working time, distance of location, not having an IUTS, not applying a new license application in moving the location, and selling liquor. The law enforcement conducted by providing verbal warning, written warning, founding, applying for the licenses, and/or business suspension. The legality of the Self-service shop must use IUTS, and Klungkung District immediately formed regulation for the Self-service shop are. The un-licensed Self-service shop are monitored and evaluated continuously and identified the licenses that have been issued. Law enforcement for unlicensed and illegal Self-service shops that are permitted to be done explicitly and consistently so as not to cause injustice in society.
\end{abstract}

\section{Abstrak}

Toko swalayan menjamur hingga ke pedesaan, namun ada yang tidak berizin, dan melanggar ketentuan perizinan. Penelitian dilakukan untuk mengidentifikasi dan menganalisa pelanggaran hukum oleh toko swalayan, dan penegakan hukum oleh SATPOL PP terhadap pelanggaran tersebut. Penelitian menggunakan metode penelitian hukum normatif; pendekatannya yaitu pendekatan perundang-undangan, konsep, dan filsafat. Sumber data terdiri atas bahan hukum primer, sekunder, 
DOI :

10.24843/JMHU.2019.v08.i02. p04

\section{Pendahuluan}

Toko swalayan dalam bentuk minimarket, supermaket, departemen store, hypermarket atau perkulakan tumbuh menjamur sampai ke desa-desa. Namun, sebagian besar belum memiliki izin yakni sebanyak 725 , sedangkan yang berizin hanya 683. Perizinan bagi toko swalayan suatu keniscayaan, sebagai legalitas untuk dapat menjalankan usaha, yaitu izin usaha toko swalayan (IUTS). Selain masalah toko swalayan illegal, ada pula pelanggaran perizinan oleh toko swalayan yang sudah berizin.

Di Kabupaten Badung, toko swalayan melebihi kuota yaitu 1.7601; di Karangasem ada yang diberikan Surat Peringatan (SP) I karena tidak berizin, di Gianyar terdapat sebanyak 30, demikian pula di Buleleng. Di Jembrana dan Denpasar terdapat pelanggaran izin, yakni buka 24 jam; dan menjual minuman beralkohol. ${ }^{2}$ Penegakan hukum terhadap toko swalayan yang melanggar hukum pun beragam, berbeda-beda antara toko swalayan yang tidak berizin dengan yang berizin tetapi melanggar perizinan. Karena itu perlu diliti mengenai pelanggaran hukum yang dilakukan oleh toko swalayan, dan bagaimana Satuan Polisi Pamong Praja (SATPOL PP) menegakkan hukum terhadap Toko swalayan yang melanggar tersebut. Identifikasi dan analisis terhadap bentuk-bentuk pelanggaran hukum perizinan oleh pengusaha toko swalayan, dan penegakan hukum oleh SATPOL PP.

1 NusaBali. (2016). Badung Hanya Butuh 1.760 Toko swalayan. http://www.nusabali.com/berita/6486/badung-hanya-butuh-1760-toko-modern.

2 Bali Tribune. Tim Yustisi Karangasem Sidak Toko swalayan - Alfa Mart Tak Berizin Terancam Disegel. http:// balitribune.co.id/content/tak-berizin-indomaret-di-sidemen-disegel.

Putu Agus Mahendra PA. Beroperasi 24 Jam - Indomart Gilimanuk Disegel Satpol PP. http:// balitribune.co.id/content/beroperasi-24-jam-indomart-gilimanuk-disegel-satpol-pp. 
Hasil penelitian bermanfaat bagi pemerintahan daerah yaitu sebagai informasi permasalahan penegakkan hukum terhadap toko swalayan, sebagai bahan untuk melakukan evaluasi terhadap pelaksanaan kebijakan penetapan perizinan toko swalayan. Masyarakat terutama pelaku usaha yang akan mendirikan toko swalayan mengetahui relevansi izin dan konsekuensi hukum jika mendirikan toko swalayan tanpa legalitas. Universitas Udayana memperoleh manfaat berupa tambahan dokumentasi hasil penelitian dalam bentuk buku dan juga soft copy mengenai penegakan hukum terhadap pelanggaran perizinan toko swalayan. Bagi Peneliti, hasil penelitian merupakan pengembangan wawasan keilmuan, yang sangat bermanfaat untuk memperkaya bahan perkuliahan mengenai kewenangan dan perizinan.

\section{Metode Penelitian}

I Made Pasek Diantha membedakan dua jenis penelitian hukum, yaitu: ${ }^{3}$ penelitian hukum normatif, yang menjadikan norma hukum sebagai obyek penelitian; dan penelitian hukum empiris yang meneliti mengenai sikap dan perilaku sosial terhadap hukum. ${ }^{4}$ Penelitian mengenai "Penegakan Hukum Terhadap Pelanggaran atas Perizinan Toko Swalayan di Wilayah Provinsi Bali" merupakan penelitian hukum normatif ${ }^{5}$ yang dipadukan dengan penelitian hukum empiris. Penelitian hukum normatif dilakukan dengan mengkaji aspek teoritis, historis, filosofis, lingkup dan materi, konsistensi, dan kekuatan mengikat peraturan perundang-undangan. Tetapi tidak mengkaji aspek implementasinya. ${ }^{6} \mathrm{Hal}$ itu dilakukan untuk menemukan kebenaran berdasarkan logika keilmuan hukum dari aspek normatif. ${ }^{7}$ Penelitian hukum empiris dimaksudkan untuk menelusuri realitas hukum mengenai penegakan hukum ketentuan perizinan toko swalayan dan kepercayaan masyarakat terhadap aparatur penegak hukum dengan cara mengumpulkan bahan non hukum. Penelusuran dan pengkajian dilakukan terhadap perundang-undangan, aspek historis, dan konsep-konsep terkait dengan perizinan toko swalayan. ${ }^{8}$ Sedangkan untuk penelitian terhadap data non hukum dilakukan dengan pendekatan kualitatif dan kuantitatif. 9 Penelitian hukum normatif dilakukan di perpustakaan pribadi, perpustakaan Fakultas Hukum Unud, dan perustakaan instansi terkait. Penelitian hukum empiris dilakukan di Kabupaten Tabanan, Badung, Klungkung, dan Kota Denpasar karena keempat lokasi itu merepresentasikan keberadaan toko swalayan dan permasalahan penegakan hukum ketentuan perizinan toko swalayan di Bali.

3 Diantha MP. (2016). Metodelogi Penelitian Hukum Normatif dalam Justifikasi Teori Hukum. Jakarta: Prenada Media Group, h.12.

4 Bandingkan dengan Fajar M, Achmad Y. (2010). Dualisme Penelitian Hukum Normatif $\mathcal{E}$ Empiris. Yogyakarta: Pustaka Pelajar. h. 28-29; Saifullah. (2018). Tipologi Penelitian Hukum Sejarah, Paradigma dan Pemikiran Tokoh di Indonesia. Bandung: PT Refika Aditama, h. 108.

5 Metode penelitian normatif merupakan salah satu penciri yang menunjukkan kharakteristik Ilmu Hukum Dogmatik. Lihat Shidarta. (2015). "Menakar Keilmiahan Ilmu Hukum Dogmatis". $\quad$ http://business-law.binus.ac.id/2015/07/25/menakar-keilmiahan-ilmuhukum-dogmatis/,

6 Muhamad AK. (2004). Hukum dan Penelitian Hukum. Bandung: Citra Aditya Bakti, h. 101.

7 Ibrahim J. (2005). Teori dan Metodelogi Penelitian Hukum Normatif. Malang: Bayu Media Publishing, h. 57.

8 Marzuki PM. (2005). Penelitian Hukum. Jakarta: Prenada Media. Hlm. 93; Diantha M P. (2016). Op. Cit., h. 156; Fajar M, Achmad Y. (2010). Op. Cit., h. 185-192.

9 Fajar M, Achmad Y. (2010). Op. Cit., h. 192. 
Penelitian menggunakan bahan hukum primer, yakni UU No. 7 Tahun 2014 tentang Perdagangan, Perpres 112/2007 tentang Penataan dan Pembinaan Pasar Tradisional, Pusat Perbelanjaan dan Toko Modern, Permendag No. 36/M-DAG/PER/9/2007 tentang Penerbitan Surat Izin Usaha Perdagangan sebagaimana telah beberapa kali diubah terakhir dengan Permendag No. 39/M-DAG/PER/12/2011, Permendag No. 68/M-DAG/PER/10/2012 tentang Waralaba untuk Jenis Usaha Toko Modern, Permendag No. 35/M-DAG/PER/7/2013 tentang Pencatuman Harga Barang dan Tarif Jasa yang Diperdagangkan, Permendag No. 56/M-DAG/PER/9/2014 tentang Perubahan atas Permendag No. 70/M-DAG/PER/12/2013 tentang Pedoman Penataan dan Pembinaan Pasar Tradisional, Pusat Perbelanjaan dan Toko Modern.

Penelitian ini juga menggunakan bahan hukum sekunder, meliputi: buku-buku, artikel, jurnal, hasil penelitian, makalah dan bahan bacaan lainnya yang terkait dengan toko swalayan. Bahan hukum tersier berupa kamus hukum, kamus Bahasa Indonesia dan bahan penunjang di luar bidang hukum tidak dapat diabaikan karena memberikan petunjuk dan memperjelas bahan hukum primer dan bahan hukum sekunder. ${ }^{10}$ Bahan-bahan hukum tersebut dilengkapi hasil wawancara dengan pejabat Dinas Penanaman Modal dan Perizinan Terpadu Satu Pintu (DPM PTSP); Dinas Koperasi, UMKM dan Perdagangan; dan SATPOL PP di Kabupaten Tabanan, Badung, Kota Denpasar, dan Kabupaten Klungkung sebagai data non hukum yang mendukung bahan hukum primer dan sekunder. ${ }^{11}$

Pengumpulan bahan hukum primer dilakukan secara sistematis merunut pada hirarki peraturan perundang-undangan. Peraturan perundang-undangan tersebut diidentifikasi untuk mengetahui relevansinya dan masih berlaku atau tidak, kemudian diklasifikasi berdasarkan prinsip lexspecialis, lex generali, lex preori, lex posteriori, lex superior, dan lex emferior. ${ }^{12}$ Bahan hukum sekunder dan tersier dikumpulkan menggunakan teknik studi dokumen ${ }^{13}$, dan dilakukan kajian pustaka dengan sistem kartu (card system) sebagai insrumennya. Pustaka yang diteliti dibaca, kemudian dicatat substansi yang relevan dalam kartu-kartu tertentu. Kartu-kartu tersebut diberikan identitas yaitu: nama pengarang, judul buku, nama penerbit, tempat penerbit, tahun, dan nomor halaman yang dikutip. ${ }^{14}$ Bahan hukum yang dikumpulkan diinventarisasi, dilakukan pengoleksian, diidentifikasi, dan diberikan kode sehingga memudahkan untuk melakukan penelusuran kembali ketika diperlukan. Data penunjang diperoleh melalui wawancara dengan istrumen dalam bentuk pedoman wawancara yang disampaikan lebih dahulu kepada responden sehingga diperoleh data sebagaimana yang dialami dalam kenyataan oleh responden atau informan.

Bahan-bahan hukum dikelompokkan berdasarkan pada hirarki dan jenis-jenisnya, kemudian diolah secara kualitatif dan kuantitatif. Selanjutnya dilakukan klasifikasi untuk mempermudah menganalisis. Analisis terhadap hasil pengolahan bahan-bahan hukum dilakukan dengan deskripsi, evaluasi, dan langkah selanjutnya yaitu melakukan interpretasi hukum terhadap substansi norma yang terkandung di dalam

10 Soekanto S dan Mamuji S. (2001). Penelitian Hukum Normatif, Suatu Tinjauan Singkat. Jakarta: PT RajaGrafindo Prsada, h. 33.

11 Marzuki PM. (2005). Op. Cit., h. 165.

12 Diantha M P. (2016). Op. Cit., h. 149, 151.

13 Saifullah. (2018). Op. Cit., h. 162.

14 Sudikni SY. (1983). Pengantar Karya Ilmiah. Cet.III. Jakarta: Aneka Ilmu, h. 37. 
bahan hukum yang dikumpulkan. ${ }^{15}$ Pada tahap akhir ditarik kesimpulan mengenai hasil identifikasi terhadap aspek hukum dalam kaitan dengan penegakan hukum terhadap pelanggaran atas perizinan toko swalayan.

\section{Hasil dan Pembahasan}

\subsection{Pengaturan dan Legalitas Toko Swalayan.}

Hasil penelitian menunjukkan bahwa pengaturan dan legalitas toko swalayan terdapat dalam UU No. 7 Tahun 2014, Perpres 112/2007, dan Permendag No. 56/MDAG/PER/9/2014 (selanjutnya ditulis Permendag 56/2014). Di Kabupaten Tabanan pengaturan dilakukan dengan Perda No. 1 Tahun 2016 dan Perbup 40/2016; di Kabupaten Badung pengaturan dengan Perda No. 3 Tahun 2017, Perbup 62/2017 dan 68/2017; di Kota Denpasar terdapat dalam Perwali 9/2009, Keputusan Walikota 188.45/495/HK/2011, dan Instruksi Walikota No. 1/2011. Di Kabupaten Klungkung tidak ada produk hukum daerah mengenai legalitas toko swalayan, sehingga menggunakan produk hukum pusat. Hal itu tampak dari Surat Edaran Bupati Klungkung No. 5112/1427.a/Diskoperindag tanggal 30 Oktober 2015.

UU No 7 Tahun 2014 mendelegasikan wewenang kepada Pemerintah Daerah untuk mengatur pengembangan, penataan dan pembinaan toko swalayan. Pelaku Usaha wajib memiliki perizinan di bidang perdagangan dari Menteri untuk melakukan kegiatan usaha toko swalayan. Menteri dapat mendelegasikan kepada Pemerintah Daerah. Perpres No. 112/2007 dan Permendag No. 56/2014 mewajibkan kepada pelaku usaha Minimarket, Supermarket, Department Store, Hypermarket dan Perkulakan untuk memiliki IUTS yang diterbitkan oleh Bupati/Walikota. IUTS untuk Minimarket diutamakan bagi UMKM setempat.

Perda Kabupaten Tabanan No. 1 Tahun 2016 mewajibkan toko swalayan memiliki IUTS, yaitu: IUTS Minimarket, IUTS Supermarket, IUTS Department Store, IUTS Hipermarket, dan IUTS Perkulakan. IUTS berlaku untuk satu usaha dan selama masih melakukan kegiatan di lokasi yang sama, masih produktif dan didaftarkan ulang setiap 5 (lima) tahun sekali. Ketentuan yang sama terdapat juga dalam Perda Kabupaten Badung No. 3 Tahun 2017 dan Perwali 9/2009. Instruksi Walikota Denpasar dan Surat Edaran Bupati Klungkung berisi perintah menghentikan penerbitan IUTS di daerahnya masing-masing.

Penelitian menemukan sebanyak 1046 toko swalayan, yang terdiri atas: 442 sudah berizin, dan 604 tidak berizin. Toko swalayan yang sudah berizin tampak pada table 1 .

15 Curzon LB. (1979). Yurisprudence. M\&E Handbooks. Estover, Plymouth PL6 7PZ: Mac Donald and Evans, Ltd., h. 253 - 255. 
Tabel 1. Toko swalayan berizin

\begin{tabular}{lllllll}
\hline No. & \multicolumn{1}{c}{ Jenis } & Tabanan & Badung & Denpasar & Klungkung & Jumlah \\
\hline 1 & Minimarket & 145 & 70 & 122 & 4 & 341 \\
\hline 2 & Departmentstore & - & 3 & 1 & - & 4 \\
\hline 3 & Supermarket & 1 & 43 & 34 & - & 78 \\
\hline 4 & Hypermarket & - & 11 & - & - & 11 \\
\hline 5 & Pusat Perbelanjaan & - & - & 8 & - & 8 \\
\hline & Jumlah & 146 & 127 & 165 & 4 & 442 \\
\hline
\end{tabular}

Sumber: Peneliti, diolah dari data yang terkumpul.

Tabel 1 menunjukan bahwa toko swalayan yang berizin, khususnya Minimarket paling banyak terdapat di Kabupaten Tabanan. Namun, toko swalayan berjejaring maupun tidak berjejaring tersebut baru memegang SIUP (Surat Izin Usaha Perdagangan) dan TDP (Tanda Daftar Perusahaan). Dengan demikian, semua belum mendapatkan IUTS yang dikeluarkan oleh BPMPD, melainkan SIUP atau TDP yang dikeluarkan oleh Diperindag sebagai rekomendasi permohonan IUTS ke BPMPD.

Di Kabupaten Badung, toko swalayan tersebar di selruh kecamatan, seperti pada table 2.

Tabel 2. Sebaran toko swalayan di Kabupaten Badung

\begin{tabular}{|c|c|c|c|c|c|c|c|c|c|c|c|c|c|}
\hline \multirow[t]{2}{*}{ No } & \multirow[t]{2}{*}{ Bidang Usaha } & \multicolumn{2}{|c|}{ Petang } & \multicolumn{2}{|c|}{ Abiansemal } & \multicolumn{2}{|c|}{ Mengwi } & \multicolumn{2}{|c|}{ Kuta Utara } & \multicolumn{2}{|c|}{ Kec. Kuta } & \multicolumn{2}{|c|}{ Kuta Selatan } \\
\hline & & AI & TI & AI & TI & AI & TI & AI & TI & AI & TI & AI & TI \\
\hline 1 & Minimarket & - & 8 & 1 & 36 & 5 & 32 & 23 & 90 & 34 & 188 & 19 & 134 \\
\hline 2 & Depart-store & - & - & - & - & - & - & - & - & - & - & - & - \\
\hline 3 & Supermarket & - & 1 & 1 & 1 & 1 & 1 & 3 & 10 & 10 & 9 & 8 & 8 \\
\hline 4 & Hypermarket & - & - & - & - & - & - & - & - & 11 & 1 & - & 1 \\
\hline 5 & Perkulakan & - & - & - & - & - & - & - & - & - & - & - & - \\
\hline & Jumlah & - & 9 & 2 & 37 & 6 & 33 & 26 & 100 & 55 & 198 & 27 & 143 \\
\hline
\end{tabular}

Keterangan: $\quad$ Kec. $=$ Kecamatan $\quad \mathrm{AI}=$ Ada Izin. $\quad \mathrm{TI}=$ Tidak ada izin

Sumber: $\quad$ Diolah dari data DPMDPTSP Badung, Januari 2013-Januari 2018.

Tabel 2 memperlihatkan bahwa toko swalayan dengan jenis bidang usaha Departmenstor dan Perkulakan tidak ada di setiap kecamatan. Toko swalayan yang berizin lebih sedikit (116) daripada yang tidak berizin (520). Toko swalayan yang sudah berizin terdiri atas pemilik IUTS (85) dan IUPP (Izin Usaha Pusat Perbelanjaan) sebanyak 31. Adanya Toko Swalayan tidak berizin tersebut disebabkan berdiri lebih dahulu daripada terbitnya Perda Kabupaten Badung No. 7 Tahun 2012, yang sudah dicabut oleh Perda No. 3 Tahun 2017. Namun keberadaan itu berlandaskan pada SIUP dan TDP yang menjadi salah satu syarat untuk memperoleh IUPP dan Izin Usaha Toko Modern (IUTM).

Di Kota Denpasar jenis perizinan sebagai legalitas toko swalayan, seperti pada tabel 3. 
Tabel 3. Izin Kegiatan Usaha Perdagangan di Denpasar

\begin{tabular}{lll}
\hline No & \multicolumn{1}{c}{ Jenis Izin } & Jumlah \\
\hline 1 & Daftar Ulang Izin Usaha Pusat Perbelanjaan (DU IUPP) & 1 \\
\hline 2 & Daftar Ulang Izin Usaha Toko Modern (DU IUTM) & 35 \\
\hline 3 & Izin Usaha Pusat Perbelanjaan (IUPP) & 7 \\
\hline 4 & Izin Usaha Toko Modern (IUTM) & 122 \\
\hline Jumlah & $\mathbf{1 6 5}$ \\
\hline \multicolumn{2}{l}{ Sumber: Data Perizinan DPMPTSP Denpasar }
\end{tabular}

Dengan demikian, legalitas toko swalayan disebut IUTM dan DU IUTM. Hal itu sesuai dengan Perwali 9/2009.

Di Kabupaten Klungkung terdapat 4 (empat) toko swalayan memiliki TDP yang dikeluarkan oleh Diskoperindag. IUTS tidak dapat dikeluarkan karena adanya Surat Edaran Bupati No. 5112/1427.a/Diskoperindag yang menunda pemberian izin untuk toko swalayan.

Deskripsi hasil penelitian tersebut di atas menunjukkan adanya permasalahan hukum mengenai penerapan dan substansi produk hukum pengaturan toko swalayan. Di Kabupaten Tabanan terjadi inkonsistensi antara norma Perda dan penerapan. Perda No. 1 Tahun 2016 menentukan legalitas toko swalayan dengan IUTS, sedangkan dalam praktik pengusaha hanya memiliki SIUP dan TDP. Dalam kaitan itu, I Gede Wayan Sucana, Kepala Bidang Pengendalian DPM PTSP Kabupaten Tabanan, yang diwawancarai pada tanggal 8 April 2018 menjelaskan bahwa toko swalayan berjejaring tidak memiliki IUTS, karena sudah terlanjur beridiri, sementara perda baru terbit tahun 2016. Hal itu menunjukkan bahwa Pembentukan Perda No. 1 Tahun 2016 kurang memenuhi aspek sosiologis, sebagai salah satu dari tiga aspek utama dalam pembentukan perda. ${ }^{16}$ Pembentukan perda tersebut mengabaikan potensi, karakteristik, dan keberadaan toko swalayan yang sudah ada di masyarakat. Perda kurang mampu menyesuaikan dengan perkembangan masyarakat yang berubah secara cepat, tidak mampu secara komprehensif untuk mengakomodir kepentingankepentingan yang ada di masyarakat ${ }^{17}$ khususnya keberadaan toko swalayan yang berkembang sangat pesat dan cepat. Pembentukan perda tersebut semestinya mengutamakan kejelasan tujuan, sebagaimana tujuan pembentukan hukum tertulis pada umumnya, yaitu mengakomodasi aspirasi masyarakat agar dapat mewujudkan kepastian hukum yang berkeadilan dan bermanfaat untuk rakyat ${ }^{18}$.

Di Kota Denpasar bentuk hukum pengaturan toko swalayan tidak sesuai dengan UU No. 7 Tahun 2014 dan Permendag No. 56/2014. Landasan hukum yang terdapat dalam bagian Mengingat Perwali 9/2009 semuanya sudah berubah, kecuali Perpres 112/2007. Pendirian Pemerintah Kota Denpasar mempertahankan Perwali 9/2009 untuk menata

${ }^{16}$ Ni'matuI Huda. (2006). “Kedudukan Peraturan Daerah dalam Hierarki Peraturan Perundangundangan". Jurnal Hukum, 1 (13), h. 26.

17 Suryadi. (2010). "Fungsi Hukum Sebagai Alat Dan Cermin Perubahan Masyarakat". Journal of Rural and Development, I (2), h. 175.

18 Febriansyah F.I. (2016). Konsep pembentukan peraturan perundang-undangan di Indonesia. Jurnal Perspektif, 21(3), h. 222. 
toko swalayan yang ada mengindikasikan terjadi negasi terhadap asas materi muatan dan pembentukan peraturan perundang-undangan dalam praktek berhukum. Perwali yang landasan hukum materialnya sudah dicabut, bahkan UU yang menjadi payung hukum penataan toko swalayan juga sudah diubah, semestinya juga diubah. Urgensi dan relvansi perubahan itu berdasarkan pada pertimbangan, paling tidak dari aspek landasan yuridis material dan formalnya, selain dari aspek materi muatan dan kesesuaian bentuk dengan materi muatan. Pembentukan suatu produk hukum semestinya menunjukkan sinkronisasi antara jenis, hierarki, dan materi muatan serta asas dengan landasan pembentukan produk hukum itu. ${ }^{19}$

Substansi Perwali 9/2009 mengenai perizinan tidak sesuai dengan ketentuan Permendag No. 56/2014 dan UU No. 7 Tahun 2014. Nomenklatur - terminology Toko Modern dan bentuk-bentuk Toko Modern yang digunakan sudah berubah, seperti tampak pada Tabel 4.

Tabel 4. Perbandingan Bentuk-bentuk Toko Swalayan

\begin{tabular}{lll}
\hline \multicolumn{1}{c}{ UU No 7 Tahun 2014 } & \multicolumn{1}{c}{ Permendag 56/2014 } & \multicolumn{1}{c}{ Perwali 9/2009 } \\
\hline \multicolumn{1}{c}{ 5enjelasan Pasal 12 (1) c } & \multicolumn{1}{c}{ Pasal 1 angka 6 Jo Pasal II } & Pasal 18 \\
\hline Bentuk Toko Swalayan: & Bentuk Toko Swalayan: & Bentuk Toko Modern: \\
1. Minimarket & 1. Minimarket & 1. Minimarket \\
2. Supermarket & 2. Supermarket & 2. Supermarket \\
3. Departement Store & 3. Department Store & 3. Toko Serba Ada \\
4. Hypermarket & 4. Hypermarket & 4. Swalayan \\
5. Grosir yang berbentuk & 5. Grosir yang berbentuk & 5. Departemen Store \\
\multicolumn{1}{c}{ Perkulakan } & \multicolumn{1}{c}{ Perkulakan } & 6. Hypermarket \\
& & 7. Perkulakan \\
\hline
\end{tabular}
9/2009.

Sumber: Diolah dari UU No. 7 Tahun 2014, Permendag 56/2014 dan Perwli

Dalam Tabel 4 tercatat adanya persamaan Bentuk-bentuk Toko Swalayan yang ditentukan dalam UU No. 7 Tahun 2014 dan Permendag No. 56/2014. Persamaan tersebut yakni terdapat 5 (lima) bentuk Toko Swalayan, seperti pada kolom 1 dan 2 dalam tabel 4. Sementara itu, di dalam Perwali 9/2009 ada 2 (dua) bentuk toko modern yang tidak ditentukan dalam UU No. 7 Tahun 2014 dan Permendag 56/2014, yaitu Toko Serba Ada dan Swalayan. Dengan demikian, dalam Perwali 9/2009 Toko Swalayan merupakan salah satu jenis toko modern; sedangkan di dalam UU No. 7 Tahun 2014 dan Permendag 56/2014 istilah toko swalayan merupakan pengganti toko modern, sehingga di dalam kedua produk hukum itu tidak dikenal lagi istilah toko modern melainkan toko swalayan.

Jenis izin usaha bidang perdagangan yang ditentukan dalam Perwali 9/2009 tidak sesuai dengan ketentuan Permendag 56/2014. Hal itu diilustrasikan dengan table 5.

${ }^{19}$ Febriansyah F.I. (2016). Ibid. 
Tabel 5. Jenis Izin Usaha Perdagangan

\begin{tabular}{lll}
\hline \multicolumn{1}{c}{ UU No. 7 Tahun 2014 } & \multicolumn{1}{c}{ Permendag 56/2014 } & \multicolumn{1}{c}{ Perwali 9/2009 } \\
\hline Pasal 24 \& Penjelasan & Pasal 24 (2) Jo. Pasal II & Pasal 18 \\
\hline Pelaku usaha wajib & Izin Usaha Pusat Perbelanjaan & IUPP: \\
memiliki perizinan di & (IUPP): & 1. Pertokoan. \\
bidang perdagangan: & 1. Pertokoan. & 2. Mall. \\
1. Izin Usaha. & 2. Mall. & 3. Plasa. \\
2. Izin Khusus. & 3. Plasa. & 4. Pusat Perdagangan. \\
3. Pendaftaran. & 4. Pusat Perdagangan. & \\
\cline { 2 - 3 } 4. Pengakuan. & Izin Usaha Toko Swalayan (IUTS): & Izin Usaha Toko Modern (IUTM): \\
5. Persetujuan. & 1. Minimarket. & 1. Minimarket \\
& 2. Supermarket. & 2. Supermarket \\
& 3. Department Store. & 3. Toko Serba Ada \\
& 4. Hypermarket. & 4. Swalayan \\
& 5. Perkulakan. & 5. Departemen Store \\
& & 6. Hypermarket \\
& & 7. Perkulakan \\
\hline
\end{tabular}

Sumber: Diolah dari UU No. 7 Tahun 2014, Permendag 56/2014 dan Perwli 9/2009.

Berdasarkan Tabel 5, Izin Usaha merupakan salah satu jenis perizinan di bidang perdagangan. Permendag 56/2014 membedakan antara IUPP dan IUTS, sedangkan Perwali 9/2009 menentukan izin usaha perdagangan terdiri atas IUPP dan IUTM. IUPP dipersyaratkan untuk bentuk usaha Pertokoan, Mall, Plasa, dan Pusat Perdagangan. Permendag 56/2014 dan Perwali 9/2009 menggunakan nama berbeda untuk perizinan perdagangan. Hal itu sebagai konsekuensi dari nomenklatur toko modern diubah menjadi toko swalayan. Perwali 9/2009 menentukan IUTS merupakan bagian dari IUTM. Hal itu menjadi rancu, sebab di satu pihak ada IUTS sementara itu ada pula IUTM yang berdampak pada pelaku usaha menjadi kebingungan. Karena itu, pemerintah Kota Denpasar mestinya sudah mengubah terminologi toko modern menjadi toko swalayan agar tidak bertentangan dengan Permendag 56/2014.

Pemerintah Kota Denpasar menetapkan Perwali 9/2009 dapat dimaklumi sebagai penggunaan kewenangan diskresi untuk mengatasi kekosongan peraturan. Perpres 112/2007 dan Permendag No. 53/M-DAG/PER/12/2008 menghendaki agar segera diadakan pengaturan mengenai penataan toko modern. Dalam keadaan mendesak tersebut tidak memungkinkan untuk membentuk peraturan daerah mengenai toko modern. Karena itulah, demi untuk kepentingan umum - pelaku usaha bidang perdagangan, maka dibentuklah Perwali 9/2009.20

Namun kini, Pemerintah Kota tidak dapat bertahan untuk tetap memberlakukan Perwali 9/2009 sebab sejak tahun 2014 sudah berlaku Permendag 56/2014 yang mencabut Permendag No. 53/M-DAG/PER/12/2008 dan Permendag 70/2013 yang menjadi landasan yuridis Perwali tersebut. Perubahan Perwali 9/2009 suatu keniscayaan demi sinkronisasi terhadap asas-asas peraturan perundang-undangan. Dalam kaitan itu, Adolf Merkl menyatakan bahwa Norma hukum mempunyai dua sisi, yaitu: Norma menengadah ke bawah (menjadi sumber norma di bawahnya), dan Norma menengadah ke atas (bersumber pada norma di atasnya). Sebagai konsekuensinya adalah suatu norma hukum dibatasi masa berlakunya oleh norma di

20 Subadi dan Tiara Oliviarizky Toersina. (2018). “Perkembangan Konsep atau Pemikiran Teoritik Tentang Diskresi Berbasis Investasi di Daerah.Mimbar Hukum-Fakultas Hukum Universitas Gadjah Mada, 30(1), h. 23. 
atasnya, yang menjadi dasar hukumnya. Dalam hal norma hukum yang menjadi sumber hukum tersebut dinyatakan tidak berlaku dan dicabut, norma hukum yang bersumber pada norma yang sudah dicabut itu juga tidak berlaku. ${ }^{21}$

Urgensi pembentukan perda sebagai pengaturan toko swalayan dimaksudkan agar pengaturan tersebut sesuai dengan politik hukum pengaturan toko swalayan yang dikehendaki UU No. 7 Tahun 2014. Itulah salah satu fungsi hukum yaitu sebagai alat bagi negara dalam mempertahankan cita-cita nasional. ${ }^{22}$ Bahkan, cita-cita politik nasional diwujudkan lebih banyak melalui hukum. Aspirasi politik masyarakat yang harus dijalankan oleh penguasa, diformulasikan dalam hukum nasional yang sekaligus sebagai alat politik. ${ }^{23}$

Kabupaten Klungkung menggunakan produk hukum pusat sebagai payung hukum penataan toko swalayan, padahal kewenangan itu sudah dilimpahkan kepada daerah, namun daerah belum membentuk produk hukum untuk itu. Kewenangan untuk menerbitkan izin merupakan kewenangan diskresi, sehingga pemerintah atas inisiatif sendiri lebih leluasa menentukan landasan, substansi dan tujuan penetapan izin. Tetapi tidak diketemukan alasan pemerintah tidak menerbitkan produk hukum mengenai toko swalayan. Pada umumnya pertimbangan dalam penerbitan izin, antara lain: kondisi-kondisi yang memungkinkan pemberian izin, cara mempertimbangkan kondisi-kondisi tersebut, akibat hukum yang diprediksi akan timbul sebagai akibat pemberian atau penolakan izin, dan tata cara serta mekanisme yang harus dipersiapkan pada saat dan sesudah penetapan diberikan, termasuk penerimaan atau pun penolakan izin. ${ }^{24}$ Permasalahan hukum dalam produk hukum itu berimplikasi terhadap penegakan hukum. Sebab dalam penegakan hukum, peranan produk hukum sebagai salah satu aspek yang perlu dipertimbangkan secara seksama. ${ }^{25}$

\subsection{Pelanggaran Hukum oleh Toko Swalayan.}

Di Kabupaten Tabanan terdapat 3 (tiga) bentuk pelanggaran toko swalayan yaitu pelanggaran jam kerja yakni toko swalayan buka selama 24 jam, melanggar ketentuan Pasal 12 huruf b Perda No. 1 Tahun 2016. Pelanggaran jarak lokasi, yaitu kurang dari 50 Meter; tetapi hal tersebut tidak dikualifikasi sebagai pelanggaran berdasarkan Pasal 14. Sebab, norma di dalam Pasal 6 dan 7 bukan norma perintah atau larangan,

${ }^{21}$ Shandra Lisya Wandasari. (2013). "Sinkronisasi Peraturan Perundang-Undangan dalam Mewujudkan Pengurangan Risiko Bencana". Unnes Law Journal 2 (2), h. 147.

22 Robert K. Merton. (1957). Social Theory and Social Structure. Chicago: the Free Press of Glencoe; Talcot Parsons. (1951). The Social System. Chicago: Free Press, h. 55. dalam Ashadi L. Diab. (2014). "Peranan Hukum Sebagai Social Control, Social Engineering Dan Social Welfare. Al'Adl, 7(2), h. 54.

23 Ashadi L. Diab. Ibid.

24 Markus Lukman, Eksistensi Peraturan Kebijakan dalam Bidang Perencanaan dan Pelaksanaan Rencana Pembangunan di Daerah Serta Dampaknya Terhadap Pembangunan Materi Hukum Tertulis Nasional, Disertasi, Universitas Padjajaran, Bandung, hlm. 189 dalam Jayantara, M. (2015). Instrumen Rekomendasi DPRD dalam Penyelenggaraan Kewenangan Perijinan oleh Pemerintah Daerah. Jurnal Magister Hukum Udayana (Udayana Master Law Journal), 4 (3), h. 506-507.

25 Yusup Moh. (2017). "Penegakan Hukum di Indonesia dalam Pandangan Teori Strukturasi Anthony Giddens dan Pemikiran Hukum Progresif". Jurnal KAPemda - Kajian Administrasi dan Pemerintahan Daerah, 10 (6), h. 47. 
sehingga tidak dapat dibebani dengan kewajiban atau sanksi. Pelanggaran atas tidak memiliki IUTS secara eksplisit diatur dalam Pasal 9 ayat (1), bahwa tanpa dilengkapi IUTS, toko swalayan itu dinyatakan melanggar hukum.

Di Kabupaten Badung, terdapat pelanggaran jam kerja dan tidak memiliki izin yang diatur dalam Pasal 35 dan Pasal 37 Perda No. 3 Tahun 2017. Pelanggaran jam kerja karena toko swalayan buka 24 jam tetapi tidak berizin berdasarkan Pasal 8 ayat (1). Adanya pelanggaran itu diakui oleh Kepala DPM-PTSP Badung. Penyimpangan jarak lokasi bukan pelanggaran. Sebab tidak termasuk dalam cakupan Pasal 35. Tidak adanya IUTS merupakan pelanggaran terhadap Pasal 37. Pelaku usaha toko swalayan yang tidak mengajukan permohonan izin baru dalam memindahkan lokasi juga dinyatakan melanggar Pasal 106 dan 37 UU No. 7 Tahun 2014.

Di Kota Denpasar terdapat tiga toko swalayan yang tidak berizin menyiasati pemerintah, dimana logo toko berjejaring itu ditutup memakai nama yang berbeda, padahal pada komputer yang digunakan terdapat logo toko berjejaring. ${ }^{26}$ Hal itu tidak sesuai dengan ketentuan Pasal 18 Perwali No. 9/2009. Ada pula penyalahgunaan izin, yakni toko swalayan dengan izin usaha pedagang eceran, tetapi melakukan penjualan menggunakan sistem toko swalayan berjejaring. Jenis barang yang dijual juga dari toko swalayan berjejaring. Pelanggaran yang lain yaitu: menjual minuman beralkohol golongan A dan jarak lokasi pendirian tempat usaha.

Di Kabupaten Klungkung terdapat 262 toko swalayan tidak berizin. Bentuk pelanggarannya yaitu: mengelabui pemerintah dengan menutup logo toko berjejaring menggunakan kertas putih, ${ }^{27}$ dan menggunakan nama lain dalam proses perizinan untuk membangun toko swalayan berjejaring. ${ }^{28}$ Kedua perbuatan itu dinyatakan pelanggaran karena Bupati Klungkung, I Nyoman Suwirta, tidak mengeluarkan izin untuk toko ritel swalayan berjaringan baru, kecuali diajukan oleh pengusaha lokal atau koperasi. Selain itu, juga melanggar ketentuan UU No. 7 Tahun 2014 dan Permendag 56/2014. Pelanggran hukum itu sesuai dengan pendapat Weber bahwa sistem hukum memiliki rasionalitas substantif dimana substansi hukum memang terdiri atas aturanaturan umum in abstracto yang siap dideduksikan guna menghukumi berbagai kasuskasus konkret. ${ }^{29}$

\subsection{Sanksi Terhadap Pelanggaran Ketentuan Toko Swalayan.}

Sanksi merupakan instrumen penegakan hukum dalam bentuk pidana penjara, sanksi perdata, dan sanksi administrasi untuk menjamin kepastian, konsistensi pelaksanaan, dan penegakan hukum bidang perizinan. Sanksi yang ditentukan di dalam produk

26 Beritabali.com. (2016). "Kuota Toko Modern Denpasar 295, Selebihnya Siap Disegel", https:/ / beritabali.com/read/2016/08/29/201608290008/Kuota-Toko-Modern-Denpasar295-Selebihnya-Siap-Disegel.html.

27 Jul. (2016). "Tidak Kantongi Ijin, Toko Modern di Klungkung Ditutup". https://suaradewata.com/read/2016/09/22/201609220017/Tidak-Kantongi-Ijin-TokoModern-di-Klungkung-Ditutup.html. (Diakses Jumat, 22 September 2017), h. 1.

28 Nusabali.com. (2016). "Pemkab Tutup Toko Modern di Koripan",http://www.nusabali.com/index.php/berita/7673/pemkab-tutup-toko-moderndi-koripan

29 Wignjosoebroto, Soetandyo. (2008). Hukum dalam Masyarakat. Malang: Bayumedia Publishing. h. 36 . 
hukum mengenai toko swalayan terdiri atas: sanksi administrasi, sanksi pidana atau denda, dan sanksi sebagaimana ditentukan dalam peraturan perundang-undangan. UU No. 7 Tahun 2014 menganut sanksi pidana penjara atau pidana denda (Pasal 106), dan sanksi administratif yaitu pencabutan izin (Pasal 37). Sedangkan Perpres 112/2007, Permendag 56/2014, Perda No. 1 Tahun 2016, Perda No. 3 Tahun 2017, dan Perwali 9/2009 menetapkan sanksi administratif secara bertahap. Toko swalayan yang melanggar, pada tahap awal diberikan peringatan tertulis, kemudian ditingkatkan dengan pembekuan izin usaha, dan terakhir berupa pencabutan izin usaha. Pembekuan izin usaha dilakukan apabila telah diberikan peringatan secara tertulis tiga kali dalam waktu tujuh hari kerja untuk setiap peringatan. Apabila pelaku usaha tidak menuruti ketentuan tersebut, maka izin usaha dicabut.

Di Kabupaten Tabanan sanksi diberikan dengan peringatan lisan, peringatan tertulis, pembinan, pengajuan izin, dan pembekuan usaha sementara. Toko swalayan yang tidak berizin dan melanggar jarak lokasi diberikan sanksi administratif berupa peringatan lisan dan tertulis, misalnya pelanggaran oleh Luwak White Coffee di Jl Jati Luwih, Soka. Toko swalayan di pertigaan Patung Jagung, Bedugul sudah mengajukan permohonan izin, tetapi lama tidak keluar. Sanksi terhadap pelanggaran tersebut hanya peringatan tertulis [Pasal 14 ayat (2)]. Sanksi pidana tidak dapat dijatuhkan karena Pasal 17 Perda No. 1 Tahun 2016 tidak mengenakan sanksi pidana bagi pelaku usaha ilegal. Dengan demikian, Pasal 17 bertentangan dengan Pasal 106 UU No. 7 Tahun 2014.

Di Kabupaten Badung, pelaku usaha yang melanggar peraturan daerah diancam sanksi administrasi dan sanksi pidana penjara atau pidana denda seperti ditentukan dalam Pasal 35 dan Pasal 37 Perda No. 3 Tahun 2017. Sanksi administrasi dijatuhkan bagi pelaku usaha yang memiliki izin. Sedangkan pelaku usaha yang tidak berizin diancam dengan pidana kurungan paling lama 6 (enam) bulan atau denda paling banyak Rp. 50.000.000, 00 (lima puluh juta rupiah). Namun tidak ada ketentuan sanksi terhadap pelanggaran jarak lokasi. Toko swalayan yang telah ada walaupun berdekatan tidak akan ditutup sepanjang tidak melebihi kuota dan berjarak tidak kurang dari 300 meter dari pasar rakyat. Toko swalayan yang berjarak kurang dari 300 meter dari pasar rakyat tidak diberikan perpanjangan izin apabila masa berlakunya izin telah berakhir sehingga tidak dapat membuka usahanya lagi di situ, melainkan harus mengajukan izin baru dan memindahkan tempat kedudukannya.

Di Kota Denpasar, Perwali 9/2009 tidak menentukan sanksi terhadap pelanggaran oleh toko swalayan. Dalam praktik, dilakukan pembinaan dan pengawasan. Jika tidak mengikuti, maka dilakukan tindakan tegas, antara lain dengan penyegelan. Di Kabupaten Klungkung dilakukan penutupan toko swalayan yang melanggar.

Hasil penelitian di atas menunjukkan bahwa produk hukum daerah tidak menentukan sanksi pidana bagi pelaku usaha yang tidak berizin, tidak ada ketentuan mengenai sanksi terhadap pelanggaran jarak lokasi toko swalayan, melanggar jenis barang yang dijual dan sistem penjualan. Dengan demikian pengutamaan penggunaan hukum tertulis dalam penataan toko swalayan tidak mampu mengakomodir masalah-masalah yang berkaitan erat dengan materi muatan produk hukum tersebut. ${ }^{30}$ Bahkan, peran hukum dalam perubahan sosial sebagai initial push dalam mencapai cita-cita yang

30 H. Yacob Djasmani. (2011). “Hukum Sebagai Alat Rekayasa Sosial dalam Praktek Berhukum di Indonesia. Masalah-Masalah Hukum,40(3),, h. 369. 
ditetapkan dalam hukum ${ }^{31}$ tidak tercapai. Di situ, sanksi hukum sebagai instrument yang datang dari luar manusia secara terorganisir, secara resmi dari otoritas tidak mampu menumbuhkan kesadaran pelaku usaha toko swalayan untuk menghayati, mematuhi, melaksanakan, dan menegakkan produk hukum daerah mengenai perizinan. ${ }^{32}$ Dalam kaitan itu, jelas bahwa pembentukan produk hukum daerah itu tidak berlandaskan pada konsep yang baik, yang direncanakan secara cermat. Sebab, jika dibentuk secara demikian, maka produk hukum itu menjadi hukum yang efektif dan mencerminkan keadilan. ${ }^{33}$

\subsection{Jenis Penegakan Hukum Terhadap Pelanggaran Perizinan Toko Swalayan.}

Penegakan hukum pada hakikatnya merupakan upaya memastikan pelaksanaan citacita pembentukan hukum oleh para otoritas dibidang penegakan hukum. ${ }^{34}$ Keberhasilan atau kegagalan penegakan hukum sudah tampak dari bagimana hukum itu dibentuk. Karena itu, produk hukum, termasuk produk hukum daerah, apalagi yang megandung norma perintah atau larangan dilengkapi dengan sanksi sebagai instrumen untuk menjamin efektivitas pelaksanaan norma hukum dan penegakan atas pelanggaran norma tersebut. Dalam kaitan itu, Jimly Asshiddiqie mengemukakan bahwa penegakan hukum merupakan proses untuk menjadikan norma-norma hukum berfungsi secara nyata sebagai pedoman melakukan hubungan hukum dalam kehidupan bermasyarakat. ${ }^{35}$ Satjipto Rahardjo menyatakan penegakan hukum merupakan upaya mewujudkan atau menjabarkan pikiran-pikiran, ide dan cita hukum yang memuat nilai-nilai keadilan dan kebenaran dari pihak otoritas yang dirumuskan dalam produk hukum menjadi kenyataan, dalam bentuk-bentuk konkrit. Untuk itu dibutuhkan suatu institusi seperti kepolisian, kejaksaan, pengadilan dan lembaga pemasyarakatan sebagai unsur klasik penegakan hukum. ${ }^{36}$ Institusi-institusi itu merupakan subyek penegakan hukum dalam arti sempit yaitu aparatur penegakan hukum tertentu yang menjamin dan memastikan tegaknya hukum, yang diperkenankan menggunakan daya paksa. ${ }^{37}$ Tetapi, Penyidik Pegawai Negeri Sipildan Satuan Polisi Pamong Praja termasuk pula penegak hukum dalam pengertian sempit. Ada pula subyek penegakan hukum dalam pengertian luas yaitu penegakan hukum

31 Satjipto Rahardjo. Hukum dan Perubahan Sosial.Bandung: Alumni, 1979, dalam Muhammad Zulfa, Kasman Abdullah, Fuad Nur. (2016). Penegakan Hukum Yang Responsif dan Berkeadilan Sebagai Instrumen Perubahan Sosial Untuk Membentuk Karakter Bangsa. Seminar Nasional "Pendidikan Ilmu-Ilmu Sosial Membentuk Karakter Bangsa Dalam Rangka Daya Saing Global" Kerjasama: Fakultas Ilmu Sosial Universitas Negeri Makassar dan Himpunan Sarjana Pendidikan Ilmu-ilmu Sosial Indonesia Grand Clarion Hotel, Makassar, 29 Oktober 2016. h. 119.

32 Sudikno Mertokusumo. (2012). Teori Hukum Edisi Revisi. Yogyakarta: Cahaya Atma Pustaka, h. $16,17$.

${ }^{33}$ Febriansyah, F. I. (2016). Op. Cit. h. 221.

34 M. Husein Maruapey. (2017). "Penegakan Hukum dan Perlindungan Negara (Analisys Kritis terhadap Kasus Penistaan Agama oleh Patahana Gubernur DKI Jakarta. JIPSI: Jurnal Ilmu Politik dan Komunikasi, 7(1), h. 24.

35 Jimly Asshiddiqie. "Penegakan Hukum"http://www.jimly.com/makalah/namafile/56/Penegakan_Hukum.pdf.

36 Satjipto Rahardjo, 1984, Masalah Penegakan Hukum - Suatu Kajian Sosiologis, Sinar Baru, Bandung, h. 24. Lihat pula Satjipto Rahardjo dalam M. Husein Maruapey. (2017), Op. Cit. h. 24.

37 Jimly Asshiddiqie. “Penegakan Hukum...", Loc. Cit. 
yang dilakukan oleh siapa saja yang melakukan atau tidak melakukan sesuatu berdasarkan pada aturan hukum yang berlaku. ${ }^{38}$

Penelitian ini memandang penegakan hukum sebagai upaya memastikan berlakunya produk hukum daerah terkait perizinan toko swalayan secara efektif, dan ditegakkan oleh SATPOL PP. Penegakan hukum dilakukan dengan penjatuhan sanksi seperti pada table 6.

Tabel 6. Penegakan Hukum Terhadap Pelaku Usaha Toko Swalayan

\begin{tabular}{llcccc}
\hline \multirow{2}{*}{ No } & \multirow{2}{*}{ Sanksi } & \multicolumn{5}{c}{ Kabupaten/Kota } \\
\cline { 2 - 6 } & & Tabanan & Badung & Denpasar & Klungkung \\
\hline 1 & Peringatan lisan & $\sqrt{ }$ & - & $\sqrt{ }$ & $\sqrt{ }$ \\
\hline 2 & Peringatan tertulis & $\sqrt{ }$ & $\sqrt{ }$ & $\sqrt{ }$ & $\sqrt{ }$ \\
\hline 3 & Pembinaan, mengajukan izin & $\sqrt{ }$ & $\sqrt{ }$ & $\sqrt{ }$ & $\sqrt{ }$ \\
\hline 4 & Pembekuan, Pencabutan & $\sqrt{ }$ & - & - & $\sqrt{ }$ \\
\hline 5 & Pidana, Denda & $\sqrt{ }$ & $\sqrt{ }$ & - & - \\
\hline
\end{tabular}

Sumber: Peneliti, diolah dari bahan hukum primer dan data penunjang.

Tabel 6 memperlihatkan bahwa penegakan hukum yang dilakukan dengan penjatuhan sanksi pidana atau denda terhadap pelaku usaha toko swalayan yang melanggar hukum terdapat di Kabupaten Tabanan dan Badung. Hal itu sesuai dengan Pasal 106 UU No. 7 Tahun 2014. Di Kota Denpasar dan Kabupaten Klungkung tidak mengenal sanksi pidana dan denda karena belum memiliki perda mengenai toko swalayan.

Penegakan hukum dengan menjatuhkan sanksi dalam bentuk peringatan tertulis, pembinaan dan pengajuan izin dilakukan di Kabupaten Tabanan, Badung, Klungkung, dan Kota Denpasar. Sementara itu, di Kabupaten Klungkung terdapat penegakan hukum dilakukan dengan memberikan peringatan lisan dan tertulis disertai dengan pembinaan dan pengajuan izin, dan pembekuan usaha sementara serta pencabutan izin. Di Kabupaten Badung penegakan hukum dilakukan hanya melalui peringatan tertulis, pembinaan dan pengajuan izin serta sanksi pidana penjara dan denda. Sedangkan di Kota Denpasar dilakukan dengan memberikan peringatan lisan, tertulis, pembinaan dan pengajuan izin.

Dalam praktik, berdasarkan pada penjelasan pihak SATPOL PP di lokasi penelitian, penegakan hukum dilakukan oleh SATPOL PP dengan menindak toko swalayan yang tidak berizin. Namun selalu didahului dengan pembinaan yang disertai dengan pernyataan dari pelaku usaha untuk segera mengurus izin, dan menutup sementara toko swalayan tersebut. Selama proses pembinaan, dilakukan monitoring selama 15 hari. Apabila pernyataan yang dibuat tidak ditindaklanjuti maka, dikeluarkan surat peringatan pertama (SP1) dengan tenggang waktu selama 7 hari. Apabila SP1 tidak diikuti, maka dikeluarkan SP2 dengan tenggang waktu 3 hari. Jika SP2 juga tidak ditindaklanjuti, maka pelaku usaha diberikan SP3 dengan batas waktu 3 hari untuk mematuhi pernyataan yang dibuat. Namun jika tetap membandel maka, Penyidik Pegawai Negeri Sipil (PPNS) melakukan penyidikan, berdasarkan pada laporan dari SATPOL PP, kemudian mengajukan kepada pengadilan.

Selain itu, tidak ada penegakan hukum yang dilakukan dengan penjatuhan sanksi pidana dan denda baik terhadap pelanggaran hukum karena tidak memiliki IUTS

38 Jimly Asshiddiqie. “Penegakan Hukum...", Loc. Cit. 
maupun pelanggaran terhadap ketentuan perizinan bagi pengusaha toko swalayan yang sudah ada IUTS. Seperti sudah disebutkan di atas bahwa terdapat 604 toko swalayan tidak berizin, namun tidak dikenakan sanksi pidana atau sanksi denda. Hal itu semata-mata karena ketentuan pidana tidak mengenakan sanksi terhadap toko swalayan yang illegal.

Deskripsi hasil penelitian di atas menunjukkan bahwa pemerintah lebih mengutamakan tindakan preventif daripada represif. Pembinaan dan menyarankan supaya dilakukan pengurusan izin di kedepankan ketimbang menjatuhkan sanksi pidana dan denda. Pemerintah Kabupaten Badung menempuh pola tersebut, padahal Pasal 37 Perda No. 3 Tahun 2017 menentukan ancaman pidana kurungan paling lama 6 (enam) bulan atau denda paling banyak Rp. 50.000.000, 00 (lima puluh juta rupiah) terhadap pelaku usaha toko swalayan yang tidak memiliki IUTS (Pasal 24), yang tidak mengajukan permohonan izin pemindahan lokasi (Pasal 26 ayat 2), dan tidak melakukan pendaftaran ulang setiap 5 (lima) tahun (Pasal 26 ayat 4). Ketentuan pidana dalam Pasal 37 berlaku juga terhadap pelanggaran Pasal 30, yaitu: pelaku usaha toko swalayan berbentuk Minimarket dilarang menjual barang produk segar dalam bentuk curah; Minimarket yang lokasinya di sekitar pemukiman penduduk, tempat ibadah, terminal, stasiun, rumah sakit, gelanggang remaja dan sekolah dilarang menjual minuman beralkohol; dilarang memaksa produsen usaha mikro, kecil, dan menengah (UMKM) yang akan memasarkan produknya di dalam toko swalayan, untuk menggunakan merek milik toko swalayan pada hasil produksi UMKM yang telah memiliki merek sendiri. Dalam kaitan itu, Philipus M. Hadjon menyatakan pemerintah lebih berhati-hati dalam pengambilan dan pembuatan keputusan dengan maksud sebagai pencegahan. Sebaliknya, pemerintah harus lebih tegas dalam pengambilan dan pembuatan keputusan terhadap pelanggaran yang dilakukan pelaku usaha ${ }^{39}$.

Di Kabupaten Tabanan, SATPOL PP tidak dapat bertindak tegas karena tidak memiliki landasan hukum dan tidak ada norma sanksi pidana. Penegakan hukum tidak dapat dilakukan dengan menjatuhkan sanksi pidana dan denda karena di dalam Pasal 17 Perda No. 1 Tahun 2016 tidak menentukan adanya sanksi pidana bagi pelaku usaha yang tidak beriizin. Pidana kurungan paling lama 3 (tiga) bulan atau pidana denda paling banyak 50.000.000,00 (lima puluh juta rupiah) ditujukan kepada setiap orang yang tidak memiliki Surat Tanda Pendaftaran Waralaba (STPW), sebagaimana ditentukan dalam Pasal 11 Perda No. 1 Tahun 2016. Pasal 9 mengandung norma perintah, yang mewajibkankan kepada setiap orang yang mendirikan toko swalayan untuk memiliki IUTS. Tetapi norma perintah itu tidak disertai dengan sanksi. Kondisi demikian berimplikasi terhadap penegakan hukum. SATPOL PP bertepuk sebelah tangan dalam menegakkan Perda. Kepatuhan terhadap perda tidak mudah terjadi apabila perdanya sendiri bernilai nominal, selama penegak hukumnya lemah, dan pengadilan bukan tempat untuk mencari kebenaran dan keadilan. Lemah kuatnya penegakan hukum oleh penegak hukum menentukan persepsi publik terhadap ada tidaknya hukum. Jika penegakan hukum lemah, maka publik beranggapan hukum tidak ada dan seolah-olah mereka berada di dalam hutan rimba. Sebaliknya, bila penegakan hukum dilakukan secara konsisten, publik menerima keberadaan hukum itu dan akan patuh. ${ }^{40}$ Karena itu, penegakan perda secara tegas, konsisten dan

39 Philipus M. Hadjon dalam Jurnal Ilmu Politik dan Komunikasi. VII (1), h. 23.

40 Zainab Ompu Jainah. (2012). “Penegakan Hukum Dalam Masyarakat.Journal of Rural and Development, 3(2), h. 167. 
memberikan keadilan sangat penting untuk menjadikan hukum itu terinternalisasi dalam sikap individu, sehingga penegakan hukum tidak perlu dilakukan setiap saat dan setiap sudut. ${ }^{41}$

Penegakan hukum ketentuan perizinan toko swalayan menuai masalah dapat dimaklumi, sebab secara umum penegakan hukum di Indonesia masih belum berjalan dengan baik dan begitu memprihatinkan. Lemahnya penegakan hukum dapat tercermin dari berbagai penyelesaian kasus yang belum tuntas. 42 Beberapa permasalahan hukum dalam penegakan hukum yaitu: pertama, pembuatan perda tidak realistis, melainkan dijadikan komoditas. Kedua, masyarakat pencari kemenangan bukan keadilan. Dalam hal ini permasalahan menjadi serius, terutama jika penegak hukum kurang berintegritas dan rentan disuap. Ketiga, uang mewarnai penegakan hukum. Uang sangat mempengaruhi putusan hakim dari peradilan terendah hingga tertinggi. Uang dapat melepaskan atau membebaskan seorang terdakwa. Keempat, penegakan hukum diskriminatif, seolah berpihak pada yang kaya, tidak kepada yang miskin. Bahkan berpihak pada mereka yang memiliki jabatan dan koneksi serta pada pejabat hukum akan akses pada peradilan. ${ }^{43}$

Padahal, sebagaimana dikemukakan oleh Moch Koesnoe bahwa Negara Indonesia sudah memiliki rechtidee sebagai nilai-nilai dasar tata hukum nasional, yang tertuang di dalam Pembukaan dan Undang-Undang Dasar Negara Republik Indonesia Tahun 1945, sebagai landasan dan sumber hukum pengembangan dan penegakan hukum. Nilai-nilai dasar tersebut, secara ringkas, yaitu: pertama, hukum berfungsi untuk melindungi, bukan sekedar memerintah. Kedua, hukum bertujuan mewujudkan keadilan sosial bagi seluruh rakyat Indonesia, yang bukan semata-mata tujuan; melainkan pegangan yang konkret dalam membuat peraturan. Ketiga, hukum bersumber dari rakyat dan mengandung sifat kerakyatan. Keempat, hukum adalah pernyataan kesusilaan dan moralitas yang tinggi baik dalam bentuk peraturan atau dalam pelaksanaannya sebagaimana yang diajarkan di dalam ajaran agama dan adatistiadat ${ }^{44}$. Penegakan hukum ketentuan perizinan toko swalayan belum sepenuhnya dijiwai oleh nilai-nilai dasar tersebut. Nilai dasar kesatu sudah tercermin dalam penegakan hukum preventif. Namun nilai dasar kedua, ketiga dan keempat belum diakomodatif, sebab penegakan hukum tidak dilakukan dengan tegas dan konsisten, bahkan terdapat kekosongan norma mengenai ancaman pidana terhadap toko swalayan yang tidak memiliki izin. Ini berdampak pada ketidakadilan bagi pelaku usaha lain terutama bagi UMKM.

41 Ibid., h. 169.

42 Ucuk Agiyanto. Penegakan Hukum Di Indonesia: Eksplorasi Konsep Keadilan Berdimensi Ketuhanan. Hukum Ransendental Pengembangan dan Penegakan Hukum di Indonesia, Retrieved from https://publikasiilmiah.ums.ac.id/bitstream/handle/11617/9722/39.\%20Ucuk\%20Agiyant o.pdf? sequence $=1 \&$ is Allowed $=\mathrm{y}$

43 Zainab Ompu Jainah. (2012). Op. Cit., h. 170.

44 Muhammad Khambali. (Juni, 2014). “Fungsi Filsafat Hukum dalam Pembentukan Hukum di Indonesia", Supremasi Hukum, 3 (1), h. 11-12. 


\section{Kesimpulan}

Pengaturan izin toko swalayan dilakukan produk hukum daerah sesuai dengan pelimpahan wewenang Menteri kepada Kepala Daerah berdasarkan Permendag 56/2014. Namun di daerah terdapat Perda Kabupaten Tabanan No. 1 Tahun 2016, Perda Kabupaten Badung No. 3 Tahun 2017, dan Perwali 9/2009. Kabupaten Klungkung belum memiliki produk hukum daerah sebagai dasar penerbitan izin. Legalitas operasional toko swalayan secara normatif berbentuk IUTS - di Kota Denpasar disebut IUTM, IUPP, DUTS, dan DUPP. Namun di dalam praktik, seperti Kabupaten Tabanan dan Klungkung masih menggunakan SIUP dan TDP.

Perilaku pelaku usaha toko swalayan yang dikualifikasi sebagai pelanggaran hukum yang ditentukan dalam produk hukum daerah pada prinsipnya merupakan pelangaran terhadap persyaratan mendirikan toko swalayan dan larangan bagi toko swalayan. Namun di dalam praktik bentuk-bentuk pelanggaran yaitu pelanggaran jam kerja, pelanggaran jarak lokasi, pelanggaran tidak memiliki IUTS, tidak mengajukan permohonan izin baru dalam memindahkan lokasi, dan menjual barang dagangan yang tidak sesuai dengan izin. Penegakan hukum terhadap pelanggaran atas perizinan toko swalayan, secara normatif dilakukan dengan menjatuhkan sanksi administratif, sanksi pidana atau denda. Dalam praktik tidak ada penjatuhan sanksi pidana dan denda; melainkan dengan memberikan peringatan lisan, peringatan tertulis, pembinaan, mengajukan izin, dan pembekuan usaha.

Sehubungan dengan terdapat beragam produk hukum daerah mengenai toko swalayan, maka Pemerintahan Daerah di wilayah Provinsi Bali sebaiknya melakukan pengaturan toko swalayan dengan Peraturan Daerah. Pemerintah Daerah Kabupaten Klungkung sebaiknya segera membentuk Perda mengenai toko swalayan.

Toko swalayan yang belum memiliki izin supaya diwajibkan mengajukan permohonan izin; kemudian dimonitoring dan dievaluasi mengenai kemajuan pengurusan izinnnya, dan diidentivikasi toko swalayan yang izinnya sudah terbit. Penegakan hukum hendaknya dilakukan dengan tegas dan konsisten sesuai dengan peraturan perundang-undangan terhadap toko swalayan yang belum mengajukan permohonan izin tetapi sudah operasional agar tidak menimbulkan ketidakadilan dalam masyarakat.

\section{Ucapan terima Kasih (Acknowledgments)}

Terimakasih diucapkan kepada seluruh pihak yang telah membantu pelaksanaan penulisan jurnal dari hasil penelitian ini terutama pada Pemerintahan Provinsi Bali, khususnya Dinas Penanaman Modal dan Pelayanan Terpadu Satu Pintu (DPMPTSP), DPMPTSP, Satuan Polisi Pamong Praja Kabupaten Tabanan, Badung, Klungkung dan Kota Denpasar; Dinas Perindustrian dan Tenaga Kerja Kabupaten Badung, Dinas Perindustrian dan Perdagangan Kota Denpasar, dan Dinas Koperasi, UKM dan Perdagangan Kabupaten Klungkung yang telah mengizinkan dan memberikan data penelitian. 


\section{Daftar Pustaka}

Buku

Curzon LB. (1979). Yurisprudence. M\&E Handbooks. Estover, Plymouth PL6 7PZ: Mac Donald and Evans, Ltd.,

Diantha M. P. (2016). Metodelogi Penelitian Hukum Normatif dalam Justifikasi Teori Hukum. Jakarta: Prenada Media Group.

Fajar M, Achmad Y. (2010). Dualisme Penelitian Hukum Normatif E Empiris. Yogyakarta: Pustaka Pelajar.

Ibrahim J. (2005). Teori dan Metodelogi Penelitian Hukum Normatif. Malang: Bayu Media Publishing.

Marzuki P.M. (2005). Penelitian Hukum. Jakarta: Prenada Media.

Muhamad A.K. (2004). Hukum dan Penelitian Hukum. Bandung: Citra Aditya Bakti.

Saifullah. (2018). Tipologi Penelitian Hukum Sejarah, Paradigma dan Pemikiran Tokoh di Indonesia. Bandung: PT Refika Aditama.

Soekanto S dan Mamuji S. (2001). Penelitian Hukum Normatif, Suatu Tinjauan Singkat. Jakarta: PT RajaGrafindo Prsada.

Sudikno M. (2012). Teori Hukum Edisi Revisi. Yogyakarta: Cahaya Atma Pustaka.

\section{Jurnal}

Djasmani, H. Y. (2011). Hukum Sebagai Alat Rekayasa Sosial dalam Praktek Berhukum di Indonesia. Masalah-Masalah Hukum, 40(3), 365-374. https:// doi.org/10.14710/mmh.40.3.2011.365-374

Diab, A. L. (2014). Peranan Hukum Sebagai Social Control, Social Engineering Dan

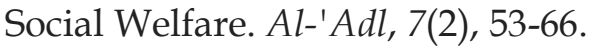

Febriansyah, F. I. (2016). Konsep pembentukan peraturan perundang-undangan di Indonesia. Jurnal Perspektif, 21(3), 220-229.

Huda, N. M. (2006). Kedudukan Peraturan Daerah dalam Hierarki Peraturan PerundangUndangan. Jurnal Hukum, 13(1), 27-37.

Jainah, Z. O. Penegakan Hukum Dalam Masyarakat.Journal of Rural and Development, 3(2). 165-172.

Jayantara, M. (2015). Instrumen Rekomendasi DPRD dalam Penyelenggaraan Kewenangan Perijinan oleh Pemerintah Daerah. Jurnal Magister Hukum Udayana (Udayana Master Law Journal), 4 (3). 502-516. https://doi.org/10.24843/JMHU.2015.v04.i03.p07

Khambali, M. (2014). Fungsi Filsafat Hukum Dalam Pembentukan Hukum Di Indonesia. Jurnal Supremasi Hukum, 3(1).

Maruapey, M. H. (2017). Penegakan Hukum dan Perlindungan Negara (Analisys Kritis terhadap Kasus Penistaan Agama oleh Patahana Gubernur DKI Jakarta. JIPSI: Jurnal Ilmu Politik dan Komunikasi, 7(1).

Subadi, S., \& Toersina, T. O. (2018). Perkembangan Konsep atau Pemikiran Teoritik Tentang Diskresi Berbasis Investasi di Daerah.Mimbar Hukum-Fakultas Hukum Universitas Gadjah Mada, 30(1), 17-31. https://doi.org/10.22146/jmh.29222

Suryadi, S. Fungsi Hukum Sebagai Alat Dan Cermin Perubahan MasyarakaT. Journal of Rural and Development,1(2).169-176.

Wandasari, S. L. (2013). Sinkronisasi Peraturan Perundang-undangan dalam mewujudkan Pengurangan Risiko Bencana.Unnes Law Journal, 2(2). 137-150.

Yusup Moh. (2017). "Penegakan Hukum di Indonesia dalam Pandangan Teori Strukturasi Anthony Giddens dan Pemikiran Hukum Progresif". Jurnal KAPemda - Kajian Administrasi dan Pemerintahan Daerah, 10 (6). 
Zulfadli, M., Abdullah, K., \& Nur, F. (2017, February). Penegakan Hukum Yang Responsif Dan Berkeadilan Sebagai Instrumen Perubahan Sosial Untuk Membentuk Karakter Bangsa. In Prosiding Seminar Nasional Himpunan Sarjana Ilmu-ilmu Sosial (Vol. 2, pp. 265-284).

\section{Online/World Wide Web}

Agiyanto, Ucuk. Penegakan Hukum Di Indonesia: Eksplorasi Konsep Keadilan Berdimensi Ketuhanan. Hukum Ransendental Pengembangan dan Penegakan Hukum di Indonesia, Retrieved from https://publikasiilmiah.ums.ac.id/bitstream/handle/11617/9722/39.\%20Ucuk \%20Agiyanto.pdf?sequence $=1 \&$ isAllowed $=\mathrm{y}$.

Bali Tribune. (2016). Tim Yustisi Karangasem Sidak Toko swalayan - Alfa Mart Tak Berizin Terancam Disegel. Retrieved from http://balitribune.co.id/content/tak-berizinindomaret-di-sidemen-disegel

Beritabali.com. (2016). "Kuota Toko Modern Denpasar 295, Selebihnya Siap Disegel", Retrieved from https://beritabali.com/read/2016/08/29/201608290008/KuotaToko-Modern-Denpasar-295-Selebihnya-Siap-Disegel.html

Jul. (2016). Suaradewata.com. “Tidak Kantongi Ijin, Toko Modern di Klungkung Ditutup". Retrieved from https://suaradewata.com/read/2016/09/22/201609220017/Tidak-KantongiIjin-Toko-Modern-di-Klungkung-Ditutup.html

NusaBali. (2016). Badung Hanya Butuh 1.760 Toko swalayan. Retrieved from http://www.nusabali.com/berita/6486/badung-hanya-butuh-1760-toko-modern

Nusabali.com. (2016). "Pemkab Tutup Toko Modern di Koripan", Retrieved from http://www.nusabali.com/index.php/berita/7673/pemkab-tutup-toko-moderndi-koripan

Putu Agus Mahendra PA. (2016). Bali Tribune. Beroperasi 24 Jam - Indomart Gilimanuk Disegel Satpol PP. Retrieved from http://balitribune.co.id/content/beroperasi-24jam-indomart-gilimanuk-disegel-satpol-pp

Shidarta. (2015). Binus University. "Menakar Keilmiahan Ilmu Hukum Dogmatis". Retrieved from http://business-law.binus.ac.id/2015/07/25/menakarkeilmiahan-ilmu-hukum-dogmatis/

\section{Peraturan Perundang-undangan}

Undang-Undang Republik Indonesia Nomor 7 Tahun 2014 tentang Perdagangan.

Peraturan Presiden Republik Indonesia Nomor 112 Tahun 2007 tentang Penataan dan Pembinaan Pasar Tradisional, Pusat Perbelanjaan dan Toko Modern.

Peraturan Menteri Perdagangan Republik Indonesia Nomor 36/M-DAG/PER/9/2007 tentang Penerbitan Surat Izin Usaha Perdagangan sebagaimana telah beberapa kali diubah terakhir dengan Peraturan Menteri Perdagangan Nomor 39/MDAG/PER/12/2011.

Peraturan Menteri Perdagangan Republik Indonesia Nomor 68/MDAG/PER/10/2012 tentang Waralaba untuk Jenis Usaha Toko Modern, Permendag No. 35/M-DAG/PER/7/2013 tentang Pencatuman Harga Barang dan Tarif Jasa yang Diperdagangkan, Permendag No. 56/M-DAG/PER/9/2014 tentang Perubahan atas Permendag No. 70/M-DAG/PER/12/2013 tentang Pedoman Penataan dan Pembinaan Pasar Tradisional, Pusat Perbelanjaan dan Toko Modern. 